\title{
Overview Of The Condition Of Sanitation Facilities Where Food Management At Sultan Hasanuddin International Airport Makassar
}

\author{
Dwi Ayu Angriany Muchtar \\ Faculty of Health Sciences, Alauddin State Islamic University, Makassar
}

ARTICLE INFO

Keywords:

Food Management At Airports, Sanitation Facilities

E-mail:

dwiayu11@gmail.com

\section{ABSTRACT}

Places for food management at Sultan Hasanuddin International Airport Makassar include restaurants and restaurants, canteens, cafes, shops and so on. One of the health requirements of a food management area that is important and affects the quality of sanitation and hygiene is sanitation facilities. Meanwhile, producers pay more attention to how to produce and serve delicious food and pay less attention to sanitation facilities. This is the background for researching the problem of sanitation facilities because sanitation facilities that do not meet health requirements will facilitate food contamination by microorganisms such as bacteria, fungi, viruses and parasites as well as chemicals that can pose risks to health. This study aims to describe the condition of sanitation facilities where food is managed at Sultan Hasanuddin International Airport Makassar in 2012. This type of research is an observational method with a descriptive approach. The population and samples were 29 places for food management. Observation sheet questionnaire used to collect data. The data was processed using the SPSS 16.0 program and presented in the form of tables and narratives. The results of the study showed that the provision of clean water in all conditions of water used $29(100 \%)$ met the requirements. There are $20(69 \%)$ eligible sewers and 9 (31\%) ineligible. There were $16(55.2 \%)$ eligible trash bins and $13(44.8 \%)$ ineligible. There are $7(24.1 \%)$ hand washing places that meet the requirements and $22(75,9 \%)$ are not eligible. There are $28(96.6 \%)$ equipment washing places that meet the requirements and $1(3.4 \%)$ do not meet the requirements. From the results of the study, it can be concluded that the water used has met the requirements, the sewerage, trash and equipment washing facilities have met the requirements, while most of the hand washing facilities did not meet the requirements. It is suggested to the government to make regulations on hygiene and sanitation for special food management for airports and it is hoped that the Angkasa Pura is to make repairs and provide proper sanitation facilities.

Copyright (C) 2020 Eduhot Journal.All rights reserved. is Licensed under a Creative Commons AttributionNonCommercial 4.0 International License (CC BY-NC

\section{INTRODUCTION}

Environmental health issues related to public health appear to be very diverse. According to the World Health Organization (WHO), environmental health is defined as the control of factors in the Description of the Condition of Sanitation Facilities for Food Management at Sultan Hasanuddin International Airport Makassar, Dwi Ayu Angriany Muchtar 
human physical environment that can have an adverse effect on physical development.[1]. Meanwhile, according to Notoatmodjo, environmental health is essentially an optimum environmental condition or condition so that it has a positive effect on the realization of optimum health status as well. RI Law No. 23 of 1992 concerning health states that environmental health includes water and air health, security of solid waste, liquid waste, gas waste, radiation and noise, control of disease factors and health or other security[2].

Environmental health problems in developing countries will get bigger and heavier with the increase in population and the rapid development of science and technology. For developed countries, environmental problems can increasingly be solved with technological capabilities that are supported by legal instruments and implementation, in addition to the production of goods that are environmentally friendly and low in waste[3]. Meanwhile, in developing countries, basic sanitation is still a big and serious problem, following other environmental health problems as a result of the negative impact of industrial products in developed countries[4]. Sanitation is a public health effort that focuses on monitoring various environmental factors that can affect the degree of environmental health. Sanitation means controlling the factors of the human physical environment so that they can adversely affect physical, spiritual and social health[5].

The basis for implementing airport environmental sanitation is the Decree of the Minister of Health 288/Menkes/SK/III/2003 concerning Guidelines for Sanitation of Public Facilities and Buildings. Public facilities and buildings are declared to meet environmental health requirements if they meet physiological, psychological needs and can prevent disease transmission between users, residents and the surrounding community, besides that they must meet the requirements for preventing accidents[6]. The operation of public facilities and buildings is outside the authority of the Ministry of Health, but these public facilities and buildings must meet health requirements. One of the public facilities and buildings at the airport is a place for food management or abbreviated as TPM[7]. Places for food management at Sultan Hasanuddin International Airport Makassar include restaurants and restaurants, canteens, cafes, taverns, snacks and so on. As one type of public service place that processes and provides food for many people, the food management place (TPM) has a large enough potential to cause health problems or disease and even poisoning as a result of the food it produces.[8].

According to Bryan (1990), in the United States disease caused by food contaminated by pathogenic microorganisms, as much as $77 \%$ of food prepared by catering businesses, $20 \%$ of cases are caused by food cooked at home and only $3 \%$ of cases are caused by food. produced by the home industry. This is similarly expressed by Gravani (1997) that 6 to 33 people per year suffer from food borne diseases. (Dita, 2010) E. coli contamination of food is still quite high in Indonesia, including in Jakarta. E. coli contamination of food by type of food management place (TPM), namely E. coli contamination of food Restaurants in hotels 33.3\%, Restaurants outside hotels 31.3\%, Jasaboga $38.2 \%$, Warung $32.9 \%$, Street vendors five $40.7 \%$ and the Food Industry $21.3 \%$. E contamination. coli at Street Vendors 22.4\%, Restaurants 26.3\%, and Jasaboga 11.8\%. From this information, it turns out that the contamination of food served to consumers is still quite high and differs according to the type of food management place (TPM).

Thus, the quality of food produced, served and sold by a food management facility (TPM) must meet health requirements. The airport also has Standard Operating Procedures for its food management areas, especially airports on an international scale. International Airport is an airport designated as an airport serving domestic flight routes and flight routes to and from abroad. Airports that apply International Standards must have food management facilities that meet standard operating procedures[9].

Hygiene sanitation for food management at airports already has standard operating procedures used for food management areas at airports. The standard operating procedure for restaurants and restaurants is the Decree of the Minister of Health of the Republic of Indonesia NO. 1098/Menkes/SK/VII/2003 concerning Sanitary Hygiene Requirements for Restaurants and Restaurants. The standard operating procedure for catering services is the Regulation of the Minister of Health of the Republic of Indonesia Number 1096/Menkes/Per/VI/2011 concerning Food Sanitation Hygiene. The standard operating procedure for street food is the Decree of the Minister of 
Health of the Republic of Indonesia NO. 942/Menkes/SK/VII/2003 concerning Guidelines for Hygiene Requirements for Snack Food Sanitation.

The Decree of the Minister of Health of the Republic of Indonesia regarding hygiene and sanitation where food management is used in airports still uses the Decree of the Minister of Health of the Republic of Indonesia in general. So that the sanitation hygiene requirements for food management both operating at the airport and outside the airport use the Decree of the Minister of Health of the Republic of Indonesia concerning the sanitation hygiene of the same food management place. Whereas Sultan Hasanuddin Makassar Airport has an international scale so that the food management area operating at the airport must be on an international scale. So that the food management area at the airport must meet the hygiene and sanitation requirements in accordance with the Decree of the Minister of Health of the Republic of Indonesia No. 1098/Menkes/SK/VII/2003 covering location and building, sanitation facilities, kitchen,

One of the health requirements for food management (TPM) that is important and affects the quality of hygiene and sanitation in restaurants and restaurants is sanitation facilities[10]. So it is very important to pay attention to sanitation facilities where food is managed because producers pay attention to how to produce and serve delicious food and do not pay too much attention to sanitation facilities. Sanitation facilities are very important because sanitation facilities that do not meet health requirements will facilitate food contamination by microorganisms such as bacteria, fungi, viruses and parasites as well as chemicals that can pose a risk to health[11].

According to the Decree of the Minister of Health of the Republic of Indonesia regarding the hygiene and sanitation requirements of restaurants and restaurants. Sanitation facilities are physical facilities of buildings and their equipment used to maintain environmental quality or control physical environmental factors that can harm human health, including clean water facilities, latrines, toilets, sewers, hand washing places, trash bins, bathrooms, work wardrobes. locker), prevention equipment against flies, mice and other animals as well as cleaning equipment[12]. The rapid development of transportation technology makes the distance between countries seem to be getting closer because the travel time is getting shorter, so that the mobility of people and goods is faster than the incubation period of infectious diseases. These conditions affect the risk of disease transmission globally. The port is a meeting point or activity in and out of ships, goods and people. As well as the gateway to the transformation of the spread of disease. And is a global threat to public health due to quarantine diseases, new infectious diseases (New Emerging Diseases) and old infectious diseases that have resurfaced (Reemerging Disease).[13]. The threat of the disease is a negative impact from the enactment of the free market or the era of globalization and can cause huge losses both in the economic, trade, socio-cultural, and political sectors that have a major impact on a country or region.[14].

\section{METHOD}

Environmental sanitation is a part of public health science that focuses on monitoring and controlling human environmental factors. Activities that include efforts to prevent and control the environment so as not to interfere with health are referred to as sanitation. Sanitation where food is handled greatly affects the quality of food produced, served and sold, therefore it must meet health requirements. One of the health requirements of a food management area that is important and affects the quality of sanitation and hygiene in a food management area is sanitation facilities. Sanitation facilities that do not meet health requirements will facilitate food contamination by microorganisms such as bacteria, fungi, viruses and parasites as well as chemicals that can pose a health risk. The application of sanitation for food management at the airport is very important, considering that the airport is an area on land and/or waters with certain boundaries that is used as a place for aircraft to land and take off, boarding and dropping passengers, loading and unloading goods and intra-travel transfers. and inter-mode transportation equipped with aviation safety and security facilities, as well as basic facilities and other supporting facilities. On the basis of the above thinking, when managing food and beverages there is no contamination, it is necessary to have sanitation facilities for food management that meet health requirements, including the following: The application of sanitation for food management at the airport is very important, considering that the airport is an area on land and/or 
waters with certain boundaries that is used as a place for aircraft to land and take off, boarding and dropping passengers, loading and unloading goods and intra-travel transfers. and inter-mode transportation equipped with aviation safety and security facilities, as well as basic facilities and other supporting facilities. On the basis of the above thinking, when managing food and beverages there is no contamination, it is necessary to have sanitation facilities for food management that meet health requirements, including the following: The application of sanitation for food management at the airport is very important, considering that the airport is an area on land and/or waters with certain boundaries that is used as a place for aircraft to land and take off, boarding and dropping passengers, loading and unloading goods and intra-travel transfers. and inter-mode transportation equipped with aviation safety and security facilities, as well as basic facilities and other supporting facilities. On the basis of the above thinking, when managing food and beverages there is no contamination, it is necessary to have sanitation facilities for food management that meet health requirements, including the following: considering that an airport is an area on land and/or waters with certain boundaries that is used as a place for aircraft to land and take off, boarding and taking off passengers, loading and unloading goods and a place for intra and intermodal transportation that is equipped with aviation safety and security facilities, as well as basic facilities and other supporting facilities. On the basis of the above thinking, when managing food and beverages there is no contamination, it is necessary to have sanitation facilities for food management that meet health requirements, including the following: considering that an airport is an area on land and/or waters with certain boundaries that is used as a place for aircraft to land and take off, boarding and taking off passengers, loading and unloading goods and a place for intra and intermodal transportation that is equipped with aviation safety and security facilities, as well as basic facilities and other supporting facilities. On the basis of the above thinking, when managing food and beverages there is no contamination, it is necessary to have sanitation facilities for food management that meet health requirements, including the following: loading and unloading of goods and places for intra and intermodal transportation that are equipped with aviation safety and security facilities, as well as basic facilities and other supporting facilities. On the basis of the above thinking, when managing food and beverages there is no contamination, it is necessary to have sanitation facilities for food management that meet health requirements, including the following: loading and unloading of goods and places for intra and intermodal transportation that are equipped with aviation safety and security facilities, as well as basic facilities and other supporting facilities. On the basis of the above thinking, when managing food and beverages there is no contamination, it is necessary to have sanitation facilities for food management that meet health requirements, including the following:

a. Clean water supply

b. Rubbish bin

c. Wastewater

d. Toilet/bathroom

e. Hand washing facilities

f. Equipment washing place

g. Employee locker

h. Equipment to prevent the entry of insects and mice.

This type of research is observational with descriptive research methods. Descriptive research method is a research method that is carried out with the main aim of making an objective description or description of a situation. The descriptive approach in this study is to obtain an overview of the condition of the sanitation facilities where food management is located at Sultan Hasanuddin International Airport Makassar The population in this study is the place of food management at Sultan Hasanuddin International Airport Makassar. The number of food management places at Sultan Hasanuddin International Airport Makassar is 29 places for food management. The sample in this study were all places of food management at Sultan Hasanuddin International Airport Makassar in 2012 as many as 29 places of food management. Observation sheet questionnaire used to collect data on the condition of sanitation facilities for food management at Sultan Hasanuddin International Airport Makassar. 
Primary data obtained from observations using a check list questionnaire. Secondary data from the Environmental Risk Control (PRL) Division of the Makassar Port Health Office (KKP), Class I Makassar Port Health Office (KKP) Annual Report and the Makassar Sultan Hasanuddin International Airport Working Area. The data obtained were then processed using the SPSS 16.0 program (statistical product and service solution). The type of analysis carried out is Univariate Analysis. This analysis is used to obtain an overview of the frequency distribution or the magnitude of the proportion based on the variables studied.

\section{RESULTS AND DISCUSSION}

Makassar Sultan Hasanuddin International Airport is located $30 \mathrm{~km}$ from Makassar City and is the border Makassar cityand Maros Regency, South Sulawesi. The number of samples as many as 33 places of food management and the results of the study showed that the number of samples was reduced by 4 places of food management so that the number of samples studied were 29 places of food management. The decrease in the number of samples was due to the fact that the food management area was no longer operating and according to information from the sanitarian staff of the Sultan Hasanuddin International Airport Makassar, the location where the food management would be built would be a hotel. Based on the results of observations made by researchers at the Food Management Center at Sultan Hasanuddin International Airport Makassar, the following research results were obtained:

Table 1 Distribution of TPM Sanitation Facilities Based on the Provision of Clean Water at Sultan Hasanuddin International Airport Makassar

\begin{tabular}{cccc} 
No. & Clean water supply & Total $(\mathbf{n})$ & Percent $(\%)$ \\
\hline 1. & Qualify & 29 & 100 \\
\hline & Amount & 29 & 100
\end{tabular}

Table 1 shows that of the 29 food management sites, 29 (100\%) of the water conditions used met the requirements.

Table 2 Distribution of TPM Sanitation Facilities Based on SPAL Sultan Hasanuddin International

\begin{tabular}{cccc} 
Airport Makassar & & \\
No. & Wastewater Sewer & Total (n) & Percent (\%) \\
\hline 1. & Qualify & 20 & 69 \\
2. & Not eligible & 9 & 31 \\
\hline & Amount & 29 & 100
\end{tabular}

Table 2 shows that the condition of the sewerage of the 29 food management sites, $20(69 \%)$ met the requirements and $9(31 \%)$ did not meet the requirements.

Table 3 Distribution of TPM Sanitation Facilities Based on Trash Bins at Sultan Hasanuddin

\begin{tabular}{|c|c|c|c|}
\hline \multirow[b]{2}{*}{ No. } & \multicolumn{2}{|c|}{ International Airport Makassar } & \multirow[b]{2}{*}{ Percent (\%) } \\
\hline & Rubbish bin & Total (n) & \\
\hline 1. & Qualify & 16 & 55.2 \\
\hline 2. & Not eligible & 13 & 44.8 \\
\hline & Amount & 29 & 100 \\
\hline
\end{tabular}

Table 3 shows that the condition of the trash bins from 29 food management places, $16(55.2 \%)$ met the requirements and $13(44.8 \%)$ did not meet the requirements.

Table 4 Distribution of TPM Sanitation Facilities Based on Handwashing Places at Sultan Hasanuddin International Airport Makassar in 2012

\begin{tabular}{cccc} 
No. & Hand washing facilities & Total $(\mathbf{n})$ & Percent $(\mathbf{\%})$ \\
\hline 1. & Qualify & 7 & 24.1 \\
2. & Not eligible & 22 & 75.9 \\
\hline & Amount & 29 & 100
\end{tabular}

Table 4 shows that the condition of the hand washing facilities from 29 food management places, 7 $(24.1 \%)$ met the requirements and $22(75.9 \%)$ did not meet the requirements.

Table 5 Distribution of TPM Sanitation Facilities Based on Equipment Wash Places at Sultan Hasanuddin International Airport Makassar

Description of the Condition of Sanitation Facilities for Food Management at Sultan Hasanuddin International Airport Makassar, Dwi Ayu Angriany Muchtar 


\begin{tabular}{cccc} 
No. & Laundry Equipment & Total $(\mathbf{n})$ & Percent (\%) \\
\hline 1. & Qualify & 28 & 96.6 \\
2. & Not eligible & 1 & 3.4 \\
\hline & Amount & 29 & 100
\end{tabular}

Table 5 shows that the condition of the washing equipment from 29 food management places, $28(96.6 \%)$ met the requirements and $1(3.4 \%)$ did not meet the requirements.

\subsection{Results}

Based on the results of observations, it was shown that of the 29 food management places at Sultan Hasanuddin International Airport Makassar which were sampled, it showed that $100 \%$ of the water used had met the physical requirements because the water conditions were odorless, tasteless and colorless. The physical condition of water that meets the requirements at the food management area at Sultan Hasanuddin International Airport Makassar cannot be separated from the water source used. The water used has gone through laboratory tests before being distributed in every food management area. So that the water used at the airport has met the physical, chemical and microorganism requirements.

The waste water referred to in this study is waste water that comes from the results of washing equipment and washing food ingredients. While the sewerage referred to in this study is the physical condition of the sewerage channel that is not clogged, watertight and closed which is found in every food management area. Based on the results of observations, it was shown that the condition of the sewerage from 29 food management sites, $20(69 \%)$ met the requirements and $9(31 \%)$ did not meet the requirements. Qualified because the condition of the sewerage is not clogged,

The trash bin in question in this study is the physical condition of the trash can made of waterproof material, has a cover and uses a plastic bag that is found in every food management place. Based on the results of observations showed that the condition of the trash bins from 29 food management places, $16(55.2 \%)$ met the requirements and $13(44.8 \%)$ did not meet the requirements. The condition of the trash that meets the requirements is because it is made of waterproof material, has a cover and uses a plastic bag and does not meet the requirements because it uses a nonwaterproof trash can in the form of cardboard, does not use a plastic bag and the trash can is open because it does not have a plastic bag.

The hand washing area referred to in this study is the condition of the hand washing place provided for consumers which is equipped with soap and dryers in every food management place. Based on the results of observations showed that the condition of the hand washing facilities of 29 food management places $7(24.1 \%)$ met the requirements and $22(75.9 \%)$ did not meet the requirements.

The equipment washing area referred to in this study is the condition of the equipment washing place used in every food management area which is made of strong, not rusty and easy to clean materials. Based on the results of observations showed that the condition of the washing equipment from 29 places for food management, $28(96.6 \%)$ met the requirements and $1(3.4 \%)$ did not meet the requirements. From these data, 28 (96.6\%) of equipment washing facilities met the requirements because they were made of strong materials, did not rust and were easy to clean, while there were 1 (3.4\%) that did not meet the requirements because of the food management area.

In this study, researchers only examined the problem of sanitation facilities for food management at Sultan Hasanuddin International Airport Makassar which include: the provision of clean water, sewerage, waste bins, hand washing facilities and equipment washing facilities. Where it is known that there are still many factors that affect the hygiene and sanitation of food management areas including location and building, kitchen, food room and employee warehouse, food ingredients and prepared food, food presentation, equipment, storage of food ingredients and ready-to-eat food, food processing/labor. Due to limited time and energy, the researcher only researched about sanitation facilities.

\subsection{Discussion}

It is hoped that the Government will make regulations on hygiene and sanitation for special 
airport food management areas; It is hoped that Angkasa Pura will pay attention to, make improvements and provide proper sanitation facilities; It is hoped that the Makassar Class I Port Health Office will be more assertive in the application of sanitation hygiene regulations for food management areas and conduct socialization about sanitation hygiene for food management areas to health workers and owners of food management areas; It is expected that the sanitarian officers will carry out inspections and monitoring of food management places that still use inadequate sanitation facilities;

\section{CONCLUSION}

From the results of physical quality research on the description of the condition of sanitation facilities where food management is located at Sultan Hasanuddin International Airport Makassar, the researchers can draw conclusions from the discussions that have been stated previously, namely as follows: All water used in food management facilities has met the physical requirements because odorless, tasteless and colorless condition; The condition of the sewerage in the food management area has mostly met the physical requirements because the condition of the sewerage is not clogged, has a cover and is watertight, while it does not meet the requirements because it does not have a cover and does not have a proper sewerage due to the space agency. the temple has not facilitated; The physical quality of the trash bins in the food management area has mostly met the physical requirements due to the condition of the trash cans being watertight, having a cover and using a plastic bag, while a small portion did not meet the requirements because they used non-waterproof trash cans, did not have a cover and did not use bags. plastics; A small number of hand washing facilities in food management facilities have qualified hand washing facilities and most do not meet the requirements because they do not have hand washing facilities; Most of the equipment washing facilities in each food processing area have met the physical requirements because they are made of strong materials,

\section{REFERENCES}

[1] T. Jiastuti, "Higiene sanitasi pengelolaan makanan dan keberadaan bakteri pada makanan jadi di rsud dr harjono ponorogo," J. Kesehat. Lingkung., vol. 10, no. 1, 2018.

[2] L. Marlinae, L. Khairiyati, F. Rahman, and N. Laily, "Buku Ajar Dasar-Dasar Kesehatan Lingkungan," Fak. Kedokt. Univ. Lambung Mangkurat Banjarbaru, 2019.

[3] S. Basri et al., "Analisis Risiko Kesehatan Lingkungan," J. Kesehat., vol. VII, no. 2, 2019.

[4] R. S. Prasetyaningsih and Y. Yulianto, "STUDI KONDISI KESEHATAN LINGKUNGAN RSUD PROF. DR. MARGONO SOEKARJO PURWOKERTO TAHUN 2016," Bul. Keslingmas, vol. 36, no. 2, 2017, doi: 10.31983/keslingmas.v36i2.2983.

[5] A. Gusti, "Sanitasi Lingkungan Pasar Tradisional Di Padang Dan Payakumbuh," J. Keselam. Kesehat. Kerja dan Lingkung., vol. 1, no. 1, 2021, doi: 10.25077/jk31.1.1.3-11.2020.

[6] "Higiene Dan Sanitasi Pada Pedagang Makanan Jajanan Bali Di Destinasi Wisata Kuliner Pasar Malam Sindu, Sanur, Bali," Journey J. Tour. Culinary, Hosp. Conv. Event Manag., vol. 1, no. 2, 2019, doi: 10.46837/journey.v1i2.27.

[7] T. Dakwani, "HIGIENE SANITASI TEMPAT PENGELOLAAN MAKANAN (TPM) DI GUDANG 100 PADA PELABUHAN LAUT TANJUNG PERAK SURABAYA TAHUN 2018," J. Kesehat. Lingkung., vol. 11, no. 1, 2019.

[8] "HIGIENE SANITASI PENGELOLAAN MAKANAN DAN ANGKA KUMAN PERALATAN MAKAN (PIRING) DI INSTALASI GIZI RUMAH SAKIT UMUM PANCARAN KASIH GMIM KOTA MANADO,” KESMAS, vol. 7, no. 5, 2019.

[9] N. Annisa, Y. Salibu, and Nurmaladewi, "Hubungan Sanitasi Lingkungan, Higiene Perorangan Dengan Kejadian Diare Pada Balita Di Wilayah Kerja Puskesmas Lainea Kabupaten Konawe Selatan,” J. Kesehat. Lingkung. Univ. Halu Oleo, vol. 1, no. 1, 2020.

[10] S. I. Trigunarso, "Hygiene Sanitasi dan Perilaku Penjamah Makanan dengan Angka Kuman pada Makanan Jajanan di Lingkungan Sekolah," J. Kesehat., vol. 11, no. 1, 2020, doi: 10.26630/jk.v11i1.1739.

[11] A. D. Moelyaningrum, "Sanitary Hygiene and Formaldehyde Content in Chicken Intestine in 
Traditional Markets of Jember Regency," J. Public Heal. Res. Community Heal. Dev., vol. 4, no. 1, 2020, doi: 10.20473/jphrecode.v4i1.15954.

[12] L. H. Napitupulu, E. Lasriany, and M. Crystandy, "Analisis Hygiene Sanitasi Tempat Penjualan Makanan dan Bakteri Escherichia coli pada Jajanan Manisan di Pasar Ramai Kota Medan," J. Healthc. Technol. Med., vol. 5, no. 1, 2019, doi: 10.33143/jhtm.v5i1.329.

[13] R. Webber, "New and emerging diseases.," in Communicable diseases: a global perspective, 2019.

[14] D. M. Elston, "New and emerging infectious diseases," J. Am. Acad. Dermatol., vol. 52, no. 6, 2005, doi: 10.1016/j.jaad.2005.02.048. 